\title{
IGF Binding Proteins in Growth-Retarded Children with Chronic Renal Failure
}

\author{
PHILLIP D. K. LEE, RAYMOND L. HINTZ, JOHN B. SPERRY, ROBERT C. BAXTER, AND
} DAVID R. POWELL

\begin{abstract}
Diabetes Research Center, Baylor College of Medicine, Houston, Texas 77054 [P.D.K.L., D.R.P.]; Department of Pediatrics, Stanford University, Stanford, California [R.L.H.]; Department of Pediatrics, Medical University of South Carolina, Charleston, South Carolina [J.B.S.]; and Department of Endocrinology, Royal Prince Alfred Hospital, Camperdown, New South Wales 2050, Australia [R.C.B.]
\end{abstract}

\begin{abstract}
Changes in the normal hormonal regulation of linear growth which lead to growth failure in children with chronic renal failure (CRF) are not well understood. Previous studies indicate that serum levels of growth hormone and IGF-I and II are normal or elevated in this population; and that serum levels of poorly defined inhibitors of IGF action are increased. Using a recently developed RIA for the 25-kD IGF-binding protein (IGF-BP25), we report significant elevations of this protein in children with CRF when compared to age- and sex-matched controls. IGF-BP25 levels correlate positively with IGF-binding activity in both populations, indicating that the RIA reflects levels of bioactive protein. Although the variation of serum IGF-BP25 with chronologic age and IGF levels are preserved in CRF, the quantitative interrelationships are disrupted. Levels of the 53-kD IGF-binding protein, an IGFbinding protein derived from the high mol wt IGF complex, were also found to be elevated in the CRF population and, unlike in the control population, did not vary with age or IGF levels. IGF-BP25 has been shown to inhibit IGF mitogenic action in vitro. Our finding of elevated levels of IGF-BP25 in children with CRF suggests that this protein may play a role in the growth retardation of pediatric chronic renal failure. The significance of the elevated IGFBP53 levels in CRF remains uncertain. (Pediatr Res $26: 308-315,1989$ )
\end{abstract}

\section{Abbreviations}

CRF, chronic renal failure

IGF-BP25, $25 \mathrm{kD}$ IGF binding protein

IGF-BP53, $53 \mathrm{kD}$ IGF binding protein
IGF-I and II, also known as the somatomedins, are peptides that mediate the mitogenic actions of growth hormone (7). Serum IGF-I levels are normal in children with CRF, whereas IGF-II levels are elevated (8).

Both IGF-I and IGF-II circulate in the serum tightly complexed to specific binding proteins (9). Most of the serum IGF is present in a $150-200 \mathrm{kD}$ serum fraction that may, in part, be covalently complexed (10). The major portion of unsaturated IGF-binding activity is found in a $30-50-\mathrm{kD}$ fraction, whereas unbound IGF is undetectable in serum. Previous studies have shown that association of IGF with an unsaturated IGF-binding protein preparation inhibits the cellular metabolic actions of IGF (11).

It has been postulated that the low mol wt unsaturated IGFbinding protein may function as a growth inhibitor in CRF. Elevated levels of unsaturated IGF-binding activity have been identified in the sera of adults and children with CRF $(12,13)$, and levels of the low mol wt IGF-binding protein measured by RIA are elevated in adults with diabetic nephropathy (14). Limited data indicate that IGF-BP25 levels are also elevated in children with CRF (15).

We have recently isolated and characterized the CDNA for the low mol wt unsaturated IGF-binding protein (IGF-BP25) isolated from the Hep-G2 human hepatoma cell line (16). This protein, which has a predicted $\mathrm{M}_{\mathrm{r}}$ of $25.274 \mathrm{kD}$, appears to be identical to the low mol wt unsaturated IGF-binding protein isolated from placenta (17) and amniotic fluid (15). Using a recently developed RIA, we demonstrate that serum IGF-BP25 levels are elevated in children with chronic renal failure as compared to agematched controls. These data support the hypothesis that alterations in IGF binding proteins may play a role in the growth retardation associated with pediatric $\mathrm{CRF}$.

\section{MATERIALS AND METHODS}

Compromised linear growth is a frequent complication of CRF in childhood (1). The factors that contribute to this growth retardation have not been well defined. Nutritional therapy and treatment of renal osteodystrophy and acidosis can lead to an improved growth rate; however, normalization of linear growth is rarely achieved $(2,3)$. This growth failure occurs in the presence of elevated growth hormone levels (4) and a probable euthyroid state $(5,6)$.

Received December 6, 1988; accepted June 7, 1989.

Correspondence and reprints David R. Powell, M.D., Diabetes Research Center, Baylor College of Medicine, 8080 North Stadium Drive, Houston, TX 77054.

Supported by a Feasibility Grant from the American Diabetes Association, Inc with funds contributed by the Colorado Chapter of the ADA (P.D.K.L.), FIRST Award DK-38773 (D.R.P.) and research award DK-24085 (R.L.H.) from the National Institutes of Health, and by the National Health and Medical Research Council, Australia (R.C.B.).
Sample collection. The study population, described in a previous report (8), consisted of 16 children with endstage renal failure and 16 age- and sex-matched healthy controls aged 1 to $14.5 \mathrm{y}$. Biochemical characteristics of the children with CRF include: serum urea $=81 \pm 26 \mathrm{mg} / 100 \mathrm{~mL}$ (mean $\pm \mathrm{SD}$ ), serum creatinine $=5.9 \pm 2.7 \mathrm{mg} / 100 \mathrm{~mL}$, serum bicarbonate $=23 \pm$ $4 \mathrm{mEq} / \mathrm{L}$, and GFR $=10 \pm 7 \mathrm{~mL} / \mathrm{min} / 1.73 \mathrm{~m}^{2}$. None of the subjects was on glucocorticoid therapy at the time of sampling. For the CRF population, ht and growth velocities averaged -3.7 \pm 1.6 and $-1.9 \pm 1.8 \mathrm{SD}$ below the means for chronologic age, respectively. All of the children with CRF had either a ht or growth velocity $>2$ SD below the mean for chronologic age, or both. The matched controls had normal heights (between 5th and 95th centiles) for chronologic age. All study subjects were prepubertal. 
Fasting morning (0800-1100 h) blood samples were collected for routine clinical testing, and sample residuals were used for this study. Blood samples were collected in nonheparinized syringes, allowed to clot, and the serum was stored at $-70^{\circ} \mathrm{C}$ until use.

Materials. (3-[ $\left.{ }^{125} \mathrm{I}\right]$ iodotyrosyl)IGF-I, $\left[\mathrm{Thr}^{59}\right]$ was obtained from Amersham Corp. (Arlington Heights, IL) and has an initial sp ac of $\sim 2000 \mathrm{Ci} / \mathrm{mmol}$. ([ $\left.{ }^{125} \mathrm{I}\right]$ iodotyrosyl)IGF-BP25 was prepared from purified Hep-G2 human hepatoma cell-derived IGFBP25 (18) using the chloramine-T method, with an initial specific activity of $\sim 1-1.5 \mathrm{Ci} / \mathrm{mmol}$. Recombinant DNA-derived [Thr ${ }^{59}$ ] IGF-I was obtained from Amgen Inc., Thousand Oaks, CA.

Dulbecco's PBS, pH 7.4 was obtained from Sigma Chemical Co., St. Louis, MO. RIA-grade, insulin-free BSA was obtained from Miles Laboratories, Inc., Kankakee, IL, Agarose-immobilized goat antirabbit IgG was obtained from BioRad Laboratories, Richmond, CA.

RIA. The IGF-BP25 RIA was performed using a polyclonal antiserum from rabbits immunized with purified Hep-G2 human hepatoma cell-derived IGF-BP25 with a highly purified monophosporyl lipid $\mathrm{A} /$ trehalose dimycolate adjuvant (RIBI ImmunoChem Research, Inc., Hamilton, MT). The assay buffer was Dulbecco's PBS, pH 7.4, 0.1\% BSA. A total of $0.1 \mathrm{~mL}$ of sample or standard and $100 \mu \mathrm{L}$ of antiserum at a 1:1000 dilution in assay buffer were incubated for $1 \mathrm{~h}$ at room temperature. Fifty $\mu \mathrm{L}$ of $\left[{ }^{125} \mathrm{I}\right] \mathrm{IGF}-\mathrm{BP}(\sim 5-10 \mathrm{~K} \mathrm{cpm})$ was then added, and the samples incubated for $18 \mathrm{~h}$ at $4^{\circ} \mathrm{C}$. A total of $1.0 \mathrm{mg}$ of agaroseimmobilized affinity-purified goat antirabbit IgG was then added for $3 \mathrm{~h}$ at room temperature. Bound counts in the pellet, obtained by centrifugation, were then determined in an automatic $\gamma$ counter. Standards were purified IGF-BP25 diluted in assay buffer, initially quantified by $\mathrm{A}^{280}$ against an ovalbumin standard (due to the small amount available) and later confirmed by comparison to a standard quantified by dry wt, which revealed superimposable displacement curves. Purity of both lots of purified IGF-BP25 used for standards were confirmed by N-terminal amino acid analysis. Nonspecific binding was determined in the presence of $100 \mu \mathrm{L}$ of Hep-G2 human hepatoma cell conditioned medium containing $20-30 \mu \mathrm{g} / \mathrm{mL}$ of IGF-BP25.

IGF-BP25 RIA data were analyzed using the IBM-PC RIA Data Reduction program (M.L. Jaffe and Assoc., Silver Spring, MD), which uses a 4-parameter logistic model originally described by Rodbard (19). All samples were assayed in duplicate and in serial dilution. Interassay coefficient of variation averaged $17.30 \pm 1.36 \mathrm{SD}$ and intraassay coefficient of variation was estimated at $13.38 \pm 3.84 \%$ at $7.86 \mathrm{ng} / \mathrm{mL}$. The detection range for the IGF-BP25 RIA was approximately $1-200 \mathrm{ng} / \mathrm{mL}$ or $0.1-$ $20 \mathrm{ng} /$ assay tube, with a total \% specific binding of $20-30 \%$.

Levels of IGF-BP53 were determined by RIA as previously described (20). As previously reported, this assay has inter- and intraassay coefficients of variation equal to $14.5 \%$ at $6.3 \mu \mathrm{g} / \mathrm{mL}$ and $5.5 \%$ at $5.7 \mu \mathrm{g} / \mathrm{mL}$; with a range of 0.1 to $20 \mathrm{ng} / \mathrm{tube}$. IGF-
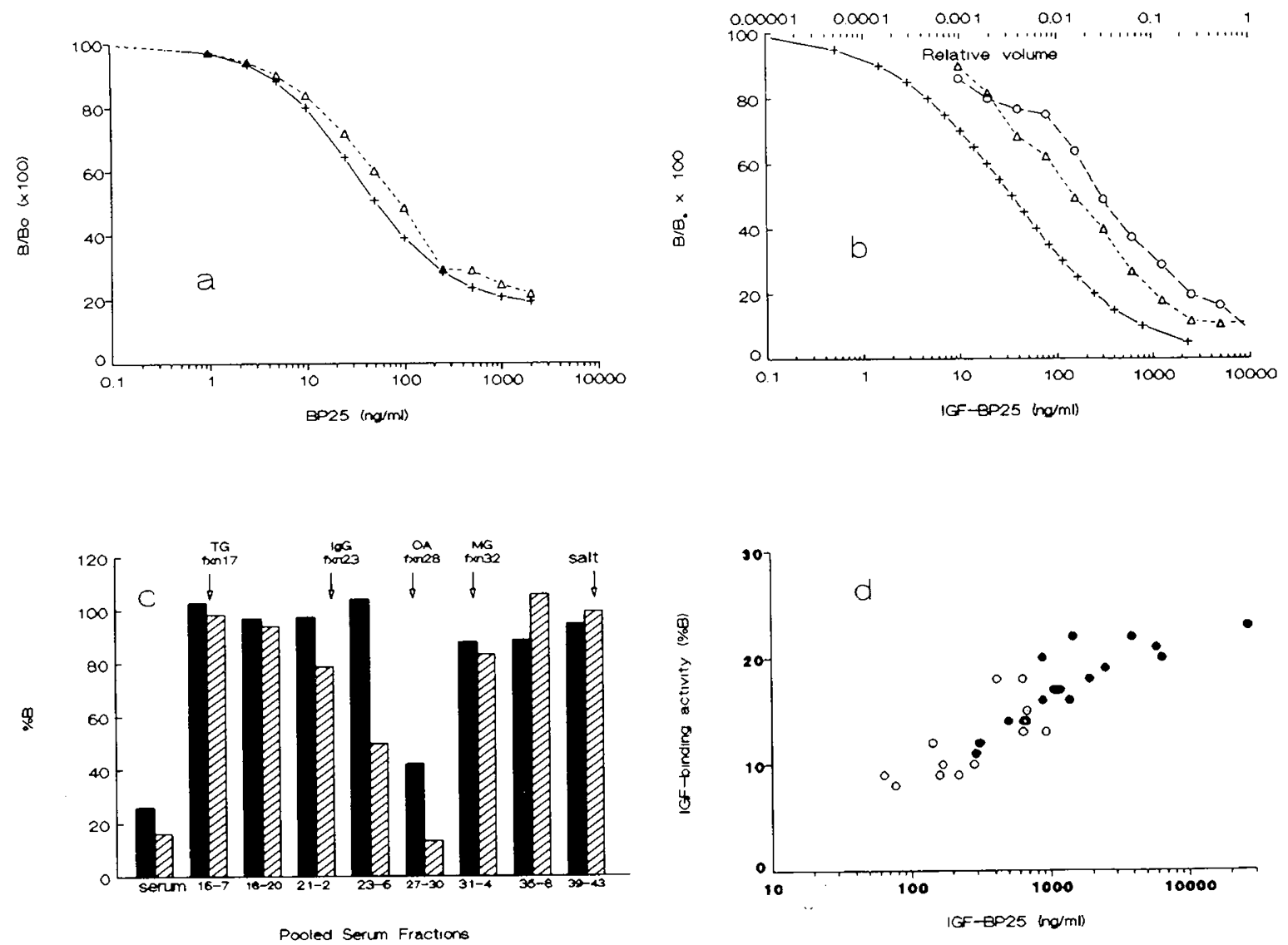

Fig. 1. Characteristics of the IGF-BP25 RIA. $a$, Identical displacement curves were obtained for purified IGF-BP25 in the absence $(+)$ and presence $(\mathbf{A})$ of $500 \mathrm{ng} / \mathrm{mL}$ IGF-I. $b$, Shows parallel displacements for purified IGF-BP25 (+), HepG2 human hepatoma cell conditioned medium $(\mathrm{O})$, and human uremic serum $(\mathbf{\Lambda})$. The purified IGF-BP25 concentrations are plotted against the bottom axis. The relative volumes of serum and HepG2 medium are plotted against the upper $\mathrm{x}$-axis, with one representing undiluted sample. c, Normal (solid bars) and uremic (cross-hatched bars) serum samples were fractionated over a calibrated S-300 column and IGF-BP25 levels in pooled fractions where determined by RIA. The first pair of bars represent unfractionated pooled samples at a 1:8 dilution. Column fractions pooled for the RIA are indicated on the bottom $x$-axis. Elution patterns for the calibration standards are indicated above the bars. The standards were thyroglobulin $(>300 \mathrm{kD})$, IgG $(150 \mathrm{kD})$, ovalbumin $(48 \mathrm{kD})$, and myoglobin $(18 \mathrm{kD})$. Maximal displacement is noted at pooled fractions $27-30$, located between the ovalbumin and myoglobin standards. $d$, Plots the correlation between IGF-BP25 (log normalized) levels by RIA and IGF-binding activity in CRF $(\bullet)$ and control (O) serum samples. Regression through all points reveals a significant correlation $\left(r=0.88, p=2 \times 10^{-11}\right)$. 
I and II levels for the pediatric CRF subjects and their age-related controls were determined after acidification and Sephadex G-50 size-exclusion chromatography of the samples. Unsaturated IGFbinding activity was determined by a charcoal-separated ligand binding assay (8). The IGF-I, IGF-II, and unsaturated IGFbinding activity data for these subjects have been previously published (8).

Data analysis. Data were analyzed using Microstat-II, v.1.5 (Ecosoft, Inc., Indianapolis, IN) on a Leading Edge model D2 personal computer. Descriptive statistics are expressed as the arithmetic mean and SD. Median and range values are also given for the nonnormal data. Differences between groups were analyzed using the Wilcoxon two-sample rank-sum test. Correlations of variables within groups were calculated by regression analysis. IGF-I and II and IGF-BP25 levels have been observed to follow a log-normal distribution for normal children; therefore, these values were log transformed for regression analysis. Log-normalization of the IGF-BP53 values had little effect on the correlative analysis. For data presentation in Figures 1-6, data that were lognormalized for analysis are plotted against a log axis according to the actual measured values. Results were considered statistically significant for $p<0.05$.

\section{RESULTS}

IGF-BP25 RIA characteristics. The IGF-BP25 RIA, which we have not previously reported, has the following characteristics;
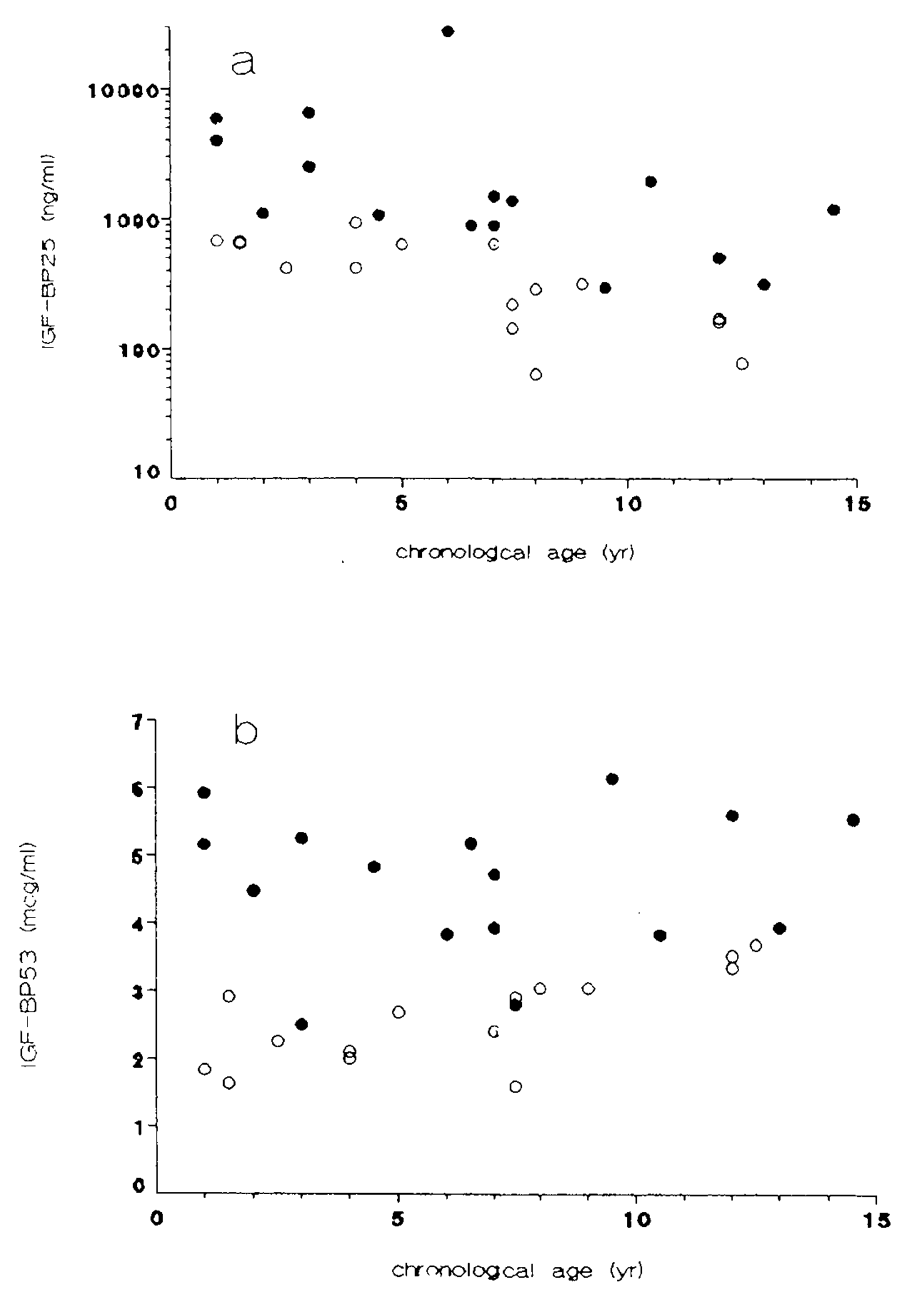

Fig. 2. Age-related trends in IGF-BP25 and IGF-BP53 levels. IGFBP25 $(a)$ and IGF-BP53 $(b)$ levels are plotted by chronological age for the CRF (O) and control $(O)$ samples. IGF-BP25 levels decline with age for the control $(r=0.76, p=0.0006)$ and for the CRF $(r=-0.56, p=$ $0.02)$ children. IGF-BP53 levels increase with age for the control $(r=$ $0.75, \mathrm{p}=0.0013)$ but not for the CRF $(r=0.05, p=0.85)$ children. freshly iodinated [ ${ }^{125}$ I]IGF-BP25 typically showed two major peaks of immunoreactivity after chromatography on a calibrated $0.9 \times 100 \mathrm{~cm}$ Sephadex G-75 column. Total \%B was approximately $50 \%$ more for peak $2(\sim 29 \mathrm{kD})$ than for peak $1(\sim 43 \mathrm{kD})$. Peak 1 may represent dimerized protein, although this was not directly shown. Peak 2 was used for the RIA.

To determine tracer stability in serum, $\sim 10^{8} \mathrm{cpm}$ aliquots of previously unchromatographed [125I]IGF-BP25 in assay buffer were incubated with $50 \mu \mathrm{L}$ of buffer, uremic serum, or normal serum in a total volume of $0.5 \mathrm{~mL}$ for $1 \mathrm{~h}$ at room temperature, followed by a $30 \mathrm{~min}$ incubation at $37^{\circ} \mathrm{C}$. The samples were then applied to a precalibrated $0.9 \times 100 \mathrm{~cm}$ Sephadex G-75 column and eluted at $1 \mathrm{~mL} / \mathrm{min}$ with collection of $1.25-\mathrm{mL}$ fractions. There was no evidence for tracer degradation, because the elution patterns were the same for all three preincubation conditions. In a separate assay, unchromatographed [ ${ }^{125}$ I]IGF-BP25 preincubated under similar conditions was found to bind with similar affinity to the anti-IGF-BP25 antiserum.

As shown in Figure 1a, preincubation of IGF-BP25 with 500 $\mathrm{ng} / \mathrm{mL}$ IGF-I (45 min, room temperature) had no effect on the displacement curve. Figure $1 b$ demonstrates the parallelism of both normal and uremic serum when compared to the purified standard. The antiserum is species specific, with sera from fetal
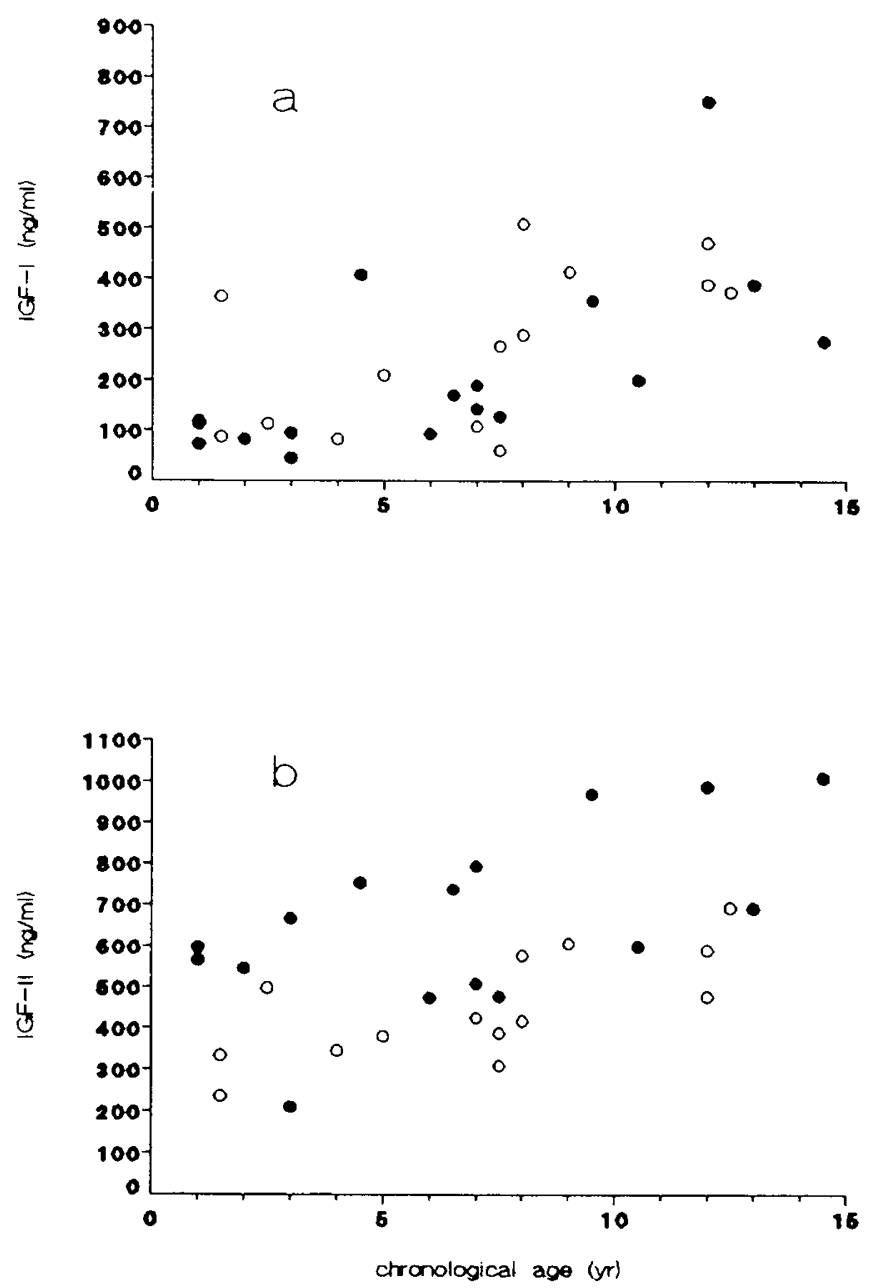

Fig. 3. Age-related trends in IGF-I and IGF-II levels. IGF-I $(a)$ and IGF-II $(b)$ are plotted by chronological age for the CRF $(\bullet)$ and control (O) samples, log IGF-I levels increase with age for both the CRF ( $r=$ $0.74, p=0.001)$ and control $(r=0.58, p=0.02)$ samples. IGF-II levels also increase with age for the CRF $(r=0.52, p=0.04)$ and control $(r=$ $0.72, p=0.004)$ samples. The graphs are plotted on linear axes for ease of interpretation. As previously reported (8), there was no difference between populations for the IGF-I levels. However, IGF-II levels are significantly higher for the CRF as compared to the matched control children $(p<0.05)$. 
cow, rat, goat, chicken, and frog showing no significant displacement.

Serum fractions were assayed to determine the size distribution of the immunoreactive moieties. Normal and uremic serum pools $(1 \mathrm{~mL})$ were applied to a calibrated $75 \mathrm{~mL} \mathrm{~S}-300$ gel column and eluted at $5 \mathrm{~mL} / \mathrm{h}$ in $50 \mathrm{mmol}$ sodium phosphate, $\mathrm{pH} 7.0,0.1 \mathrm{M} \mathrm{NaCl}$. The mean IGF-BP25 levels for the individual samples pooled for this assay were $1550 \pm 742 \mathrm{ng} / \mathrm{mL}$ for the uremic pool, and $352 \pm 314 \mathrm{ng} / \mathrm{mL}$ for the normal pool. As shown in Figure $1 c$, a single major immunorsactive peak roughly corresponds to the expected mol wt calibration range.

IGF-BP25 levels. The levels of IGF-BP 25 determined by RIA correlated with unsaturated binding activity determined by the charcoal-separated ligand-binding assay $\left(r=0.88, p=2 \times 10^{-11}\right)$, suggesting that the two assays quantify identical proteins (Fig. $1 d)$. This correlation was consistent for the CRF patients $(r=$ $0.84, p=0.00004)$ and the matched controls $(r=0.74, p=$ $0.001)$.

Average IGF-BP25 levels were significantly higher for the CRF children $(3576 \pm 6584 \mathrm{ng} / \mathrm{mL}$, median $1279 \mathrm{ng} / \mathrm{mL}$, range 294$27,225 \mathrm{ng} / \mathrm{mL})$ as compared to the controls ( $403 \pm 264 \mathrm{ng} / \mathrm{mL}$, median $364 \mathrm{ng} / \mathrm{mL}$, range $64-931 \mathrm{ng} / \mathrm{mL}$ ), and IGF-BP25 levels were significantly higher for the CRF subject in each matched pair. As shown in Figure $2 a$, an age-related negative trend for immunoassayable IGF-BP25 levels was observed for the controls $(r=-0.76, p=0.0006)$ and for the children with CRF $(r=$ $-0.56, p=0.02)$.

To examine the possibility that the increased IGF-BP25 levels in CRF were related to a delay in gonadal hormone maturation, levels for the four CRF children above the age of $10 \mathrm{y}$ were compared with four sex-matched controls between 7 and 9 y of age. The levels for the CRF children were significantly elevated relative to the younger controls. Unfortunately, sex steroid levels were not directly measured for the study subjects. IGF-BP25 levels did not correlate with nutritional intake (percent recommended daily allowance) for the $11 \mathrm{CRF}$ children who provided written dietary histories $(r=-0.002, p=0.99)$.

$I G F-B P 53$ levels. IGF-BP53 levels were significantly elevated for the CRF children $(4.60 \pm 1.06 \mu \mathrm{g} / \mathrm{mL})$ as compared to controls $(2.59 \pm 0.68 \mu \mathrm{g} / \mathrm{mL})$. As shown in Figure $2 b$, the IGFBP53 levels showed a positive correlation with age for the control children $(r=0.75, p=0.001)$, but not for the children with CRF $(r=0.05, p=0.8)$. IGF-BP53 levels showed a negative correlation with IGF-binding activity for the controls $(r=-0.59, p=0.03)$ but not for the CRF children $(r=-0.10, p=0.70)$.

$I G F-I$ and IGF-II levels. For both study groups, log-normal IGF-I and IGF-II levels positively correlated with age (Figs $3 a$ and $b$ ). As previously reported (8), no significant difference for IGF-I levels between the children with CRF $(220 \pm 182 \mathrm{ng} / \mathrm{mL}$, median $156 \mathrm{ng} / \mathrm{mL}$, range $45-753 \mathrm{ng} / \mathrm{mL})$ and their matched controls $(248 \pm 155 \mathrm{ng} / \mathrm{mL}$, median $268 \mathrm{ng} / \mathrm{mL}$, range $60-510$ $\mathrm{ng} / \mathrm{mL}$ ) was observed. However, IGF-II levels were significantly elevated for the CRF population $(661 \pm 213 \mathrm{ng} / \mathrm{mL}$, median 632 $\mathrm{ng} / \mathrm{mL}$, range $210-1009 \mathrm{ng} / \mathrm{mL}$ ) as compared to the controls $(433 \pm 139 \mathrm{ng} / \mathrm{mL}$, median $420 \mathrm{ng} / \mathrm{mL}$, range $237-692 \mathrm{ng} / \mathrm{mL})$.

As illustrated in Figure 4, IGF-I levels negatively correlated with IGF-BP25 for both the control $(r=-0.63, p=0.01)$ and CRF ( $r=-0.63, p=0.009)$ populations. Similarly, IGF-II levels negatively correlate with IGF-BP25 for the control $(r=-0.64, p$ $=0.01)$ and CRF $(r=-0.63, p=0.01)$ populations.

IGF-I positively correlates with IGF-BP53 for the controls $(r$ $=0.92, p=0.000004)$, but not for the CRF $(r=0.38, p=0.14)$
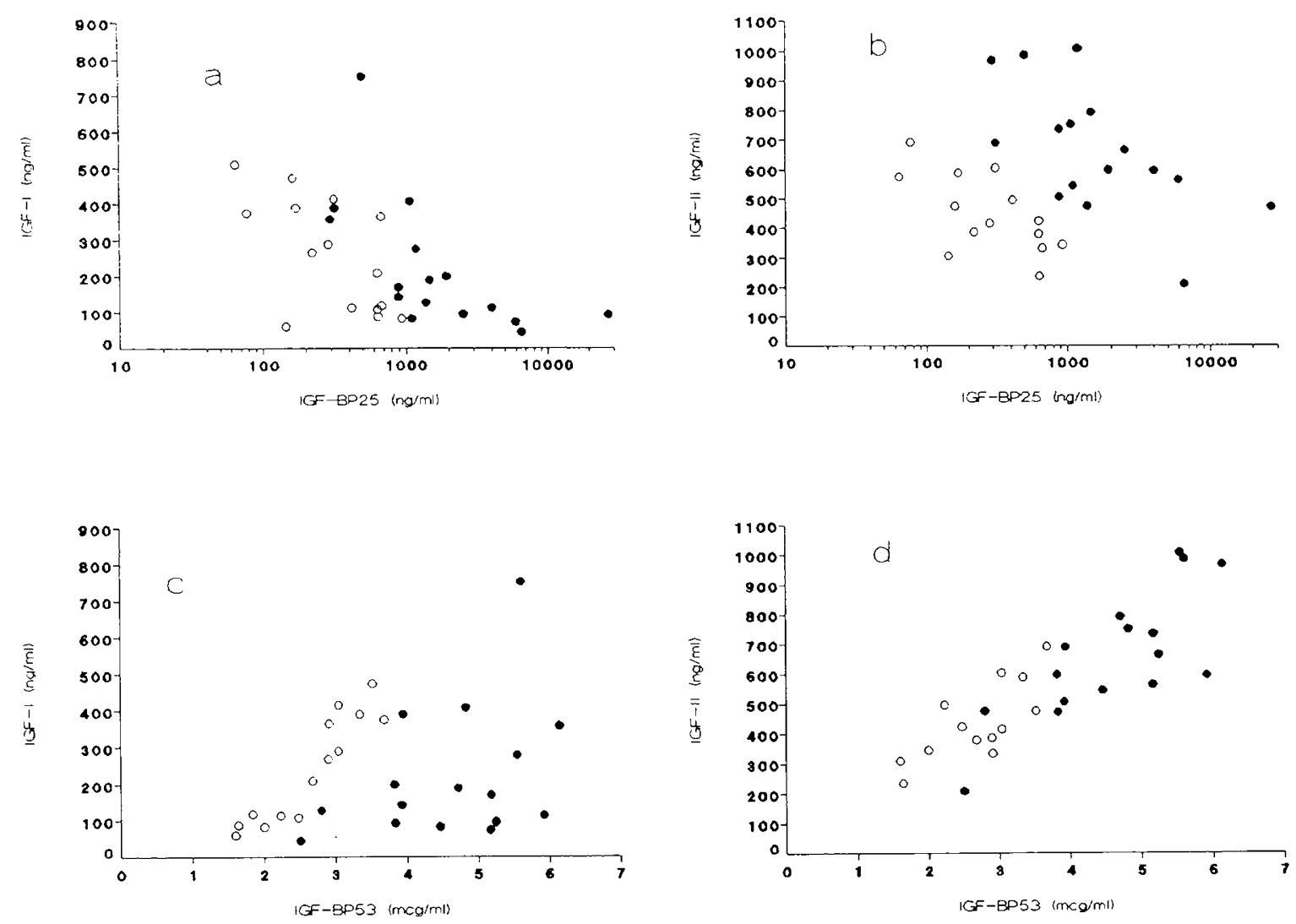

Fig. 4. IGF-BP25, IGF-BP53, and IGF-I and II cross-correlations. Correlations between the levels of the IGF and their binding proteins are depicted for the CRF $(\bullet)$ and matched control $(O)$ populations. $a$, IGF-I levels negatively correlate with IGF-BP25 levels for the control $(r=0.63$, $p=0.012)$ and for the CRF $(r=0.63, p=0.009)$ children. $b$, IGF-II levels negatively correlate with IGF-IB25 levels for the control $(r=-0.64, p=$ $0.01)$ and for the CRF $(r=-0.63, p=0.01)$ children. $c$, IGF-I levels increase with IGF-BP53 levels for the control $(r=0.92, p=0.000004)$ but not for the CRF $(r=0.38, p=0.14)$ children. $d$, IGF-II levels increase with IGF-BP53 levels for both the control $(r=0.75, p=0.003)$ and CRF $(r=$ $0.78, p=0.0004)$ children. 
children. IGF-II positively correlates with IGF-BP53 for both the control $(r=0.75, p=0.003)$ and CRF $(r=0.78, p=0.0004)$ populations.

Molar ratios. To further investigate the molecular interrelationships of the IGF and the IGF-BP, the measured concentrations of these peptides were converted to molar concentrations and compared. Mol wt used for the conversions were $7.5 \mathrm{kD}$ for IGF-I and II, $25 \mathrm{kD}$ for IGF-BP25 and $53 \mathrm{kD}$ for IGF-BP53.

The ratio of the molar concentrations of IGF-I to IGF-BP25 was $5.42 \pm 7.58$ for the controls and $1.16 \pm 1.71$ for the CRF children. IGF-II to IGF-BP25 molar ratios were $8.66 \pm 9.94$ and $2.71 \pm 3.14$, respectively. Total IGF to IGF-BP25 molar ratios were $14.44 \pm 17.48$ for the controls and $3.88 \pm 4.76$ for the CRF children. All three ratios were significantly decreased $(p<0.01)$ for the CRF subjects relative to their controls. As shown in Figure $5 a, \log$ (total mol IGF/mol IGF-BP25) showed a significant increase with age for both the control $(r=0.79, p=0.0007)$ and CRF children $(r=0.62, p=0.01)$.

IGF-I to IGF-BP53 molar ratios were $0.59 \pm 0.25$ for the controls and $0.33 \pm 0.24$ for the CRF children, and IGF-II to IGF-BP43 molar ratios were $1.16 \pm 0.22$ and $1.01 \pm 0.21$, respectively. Total IGF to IGF-BP53 molar ratios were $1.76 \pm$ 0.30 for the controls, and $1.34 \pm 0.42$ for the CRF children. All three ratios were significantly $(p<0.05)$ decreased for the CRF subjects relative to their controls. As shown in Figure $5 b$, the total IGF to IGF-BP53 molar ratios increased with age for both the normals $(r=0.68, p=0.01)$ and CRF $(r=0.82, p=0.0001)$. Furthermore, as shown in Figure 6, the total IGF to IGF-BP53 molar ratios correlated with total IGF levels for both the controls $(r=0.86, p=0.0002)$ and CRF $(r=0.85, p=0.00003)$ subjects.

\section{DISCUSSION}

Early studies of the low mol wt unsaturated IGF-binding protein were limited by the lack of purified protein, and quantitation relied upon assays of IGF-binding activity. These studies have shown that the low mol wt circulating IGF-binding activity increases in the presence of growth hormone deficiency (21) and in CRF (8). Recent progress, including the investigations reported here, allow direct quantitation of this IGF-binding protein.

Our IGF-BP25 RIA is similar to that developed in other laboratories, and we have found that levels in normal nonfasting children and adults (Lee PDK, Powell DR, unpublished data) are comparable to levels reported by others $(22,24,25)$, IGFBP25 levels for large groups of fasting children have not been published. To avoid the reported diurnal variation of circulating IGF-BP25 levels (25), all samples used in the study and control populations were collected in the morning after an overnight fast.

As we have previously reported for the childhood CRF and matched control subjects (8), the IGF-I levels do not differ between the two groups, and the IGF-II levels are significantly elevated for the CRF group. It is of interest that both IGF-I and IGF-II show an age-related increase with age, whereas previous studies have shown no relationship of IGF-II levels with age (26). This may be due to the controlled conditions of sampling, although we have no direct evidence for this.

Our data show elevated levels of IGF-BP25 in children with CRF and growth retardation as compared to age and sex-matched controls. These findings are in agreement with previous reports of elevated levels of IGF-BP25 in adults with uremia associated with diabetes mellitus and in a limited population of children with CRF $(14,15)$. The close correlation with IGF-binding activity and the size fractionation of the immunoreactivity indicates that the elevated levels represent an actual increase of bioactive IGF-BP25 rather than simply decreased clearance of immunoreactive, biologically inactive, metabolized protein. Furthermore, although the molar ratios of IGF to IGF-BP25 increased peripubertally for all three pediatric groups studied, the ratios were significantly lower for the CRF group. Although the
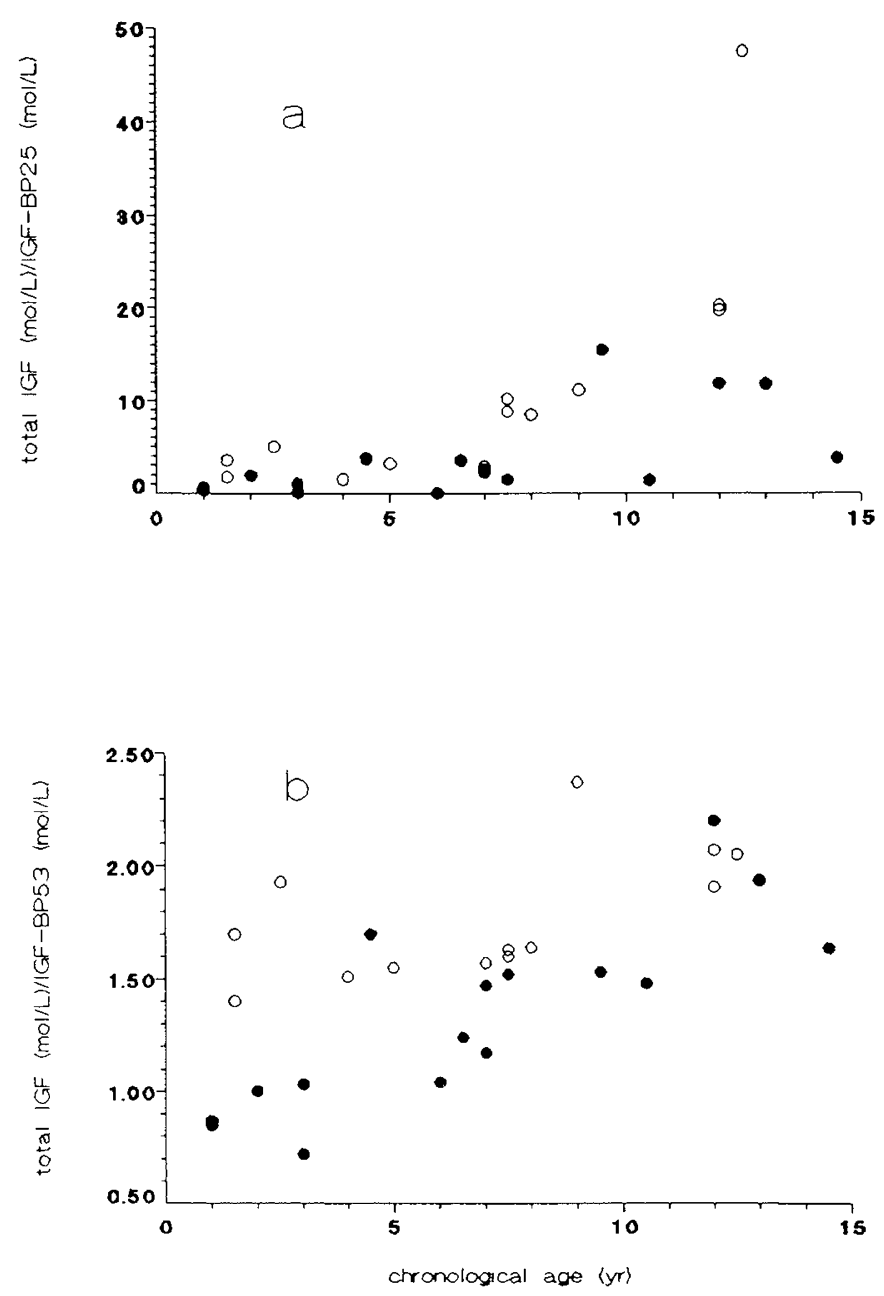

Fig. 5. Molar ratios of total IGF to IGF-BP25 and IGF-BP53. The molar concentrations of total IGF (IGF-I + IGF-II) were compared to the molar concentrations of IGF-BP25 $(a)$ and IGF-BP53 $(b)$ for the $\mathrm{CRF}(\mathbf{O})$ and matched control $(O)$ populations. The molar ratio of IGF to IGF-BP25 increased with chronologic age for both the control $(r=$ $0.79, p=0.0007)$ and CRF ( $r=0.62, p=0.01)$ groups. IGF to IGFBP53 molar ratios increased with age for the both the controls $(r=0.68$, $p=0.01)$ and $\operatorname{CRF}(r=0.82, p=0.0001)$ subjects.

duration of fasting before sample collection was not strictly controlled, the variability that might result from minor variations in the duration of overnight fasting would not explain the large between-group differences in IGF-BP25 levels observed.

The possible physiologic significance of the elevated IGF-BP25 levels is suggested by previous investigations of this protein. Although IGF-BP25 has been reported to enhance the mitogenic effect of IGF-I for fibroblasts (27), this protein inhibits IGF bioactivity in most other systems studied. Unsaturated low mol wt IGF-BP $(11)$ or purified IGF-BP25 $(28,29)$ leads to inhibition of IGF receptor binding and IGF-stimulated mitogenesis and cell metabolism in vitro. Infusion of IGF-I into rodents and humans leads to an acute insulin-like effect, followed by a decline in this effect coincident with the association of IGF-I with serum fractions containing IGF-BP25 (30, 31). Furthermore, infusion of mutant forms of IGF-I that bind to the IGF-I receptor but not to IGF-BP25 leads to a prolongation of the insulin-like effects $(32,33)$. Addition of purified IGF-BP25 to chick embryo cartilage in vitro leads to inhibition of IGF-I stimulated DNA and proteoglycan synthesis (34). In view of these observations, our data suggest that elevations of the IGF-inhibitory protein in CRF may contribute to the growth retardation associated with this disorder. The possible physiologic effects of elevated IGF-BP25 

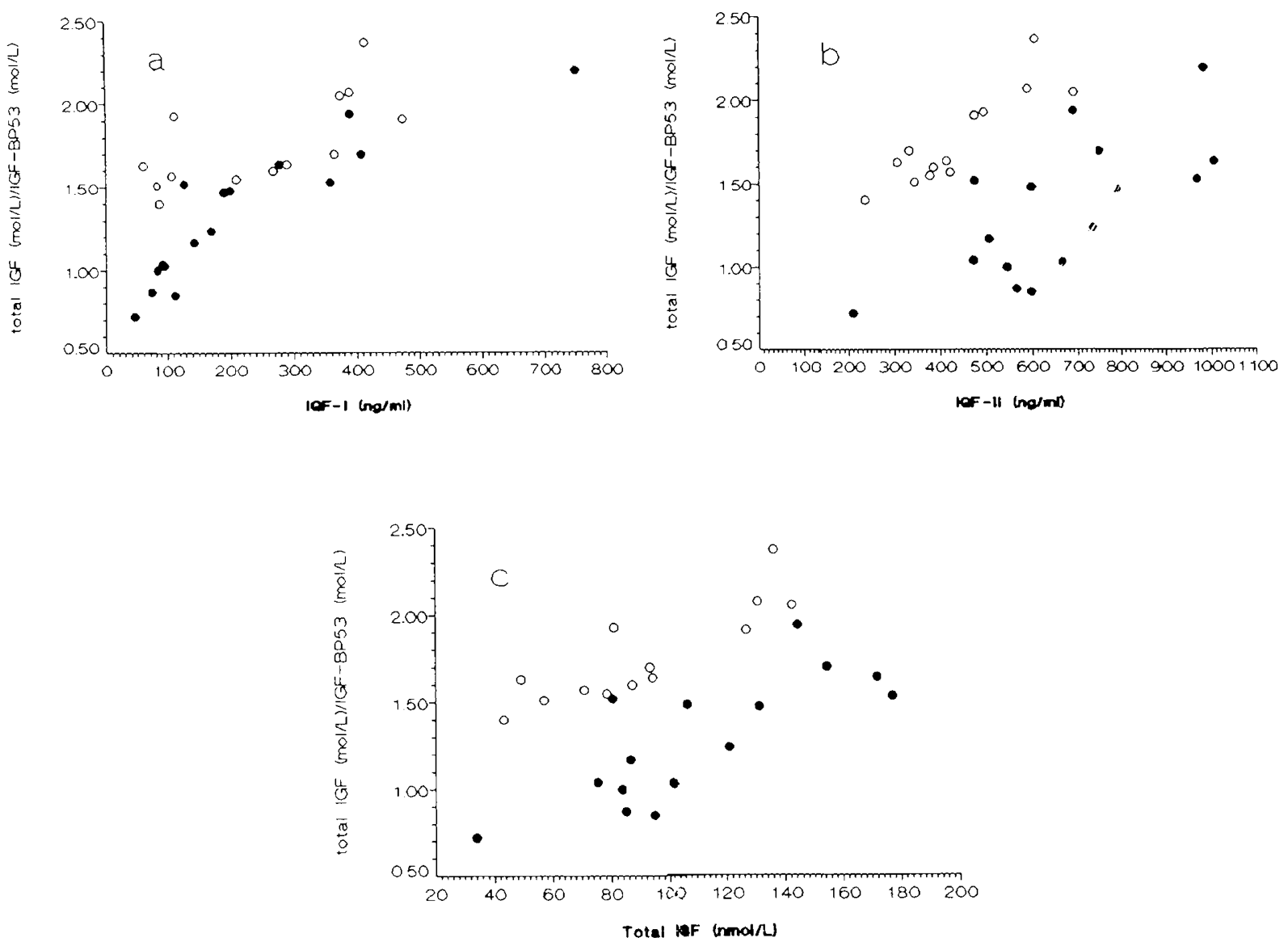

Fig. 6. Relationship of IGF levels to IGF/IGF-BP53 molar ratios. $a$, The molar ratio of total IGF to IGF-BP53 varied with IGF-I leveis for both the control $(r=0.68, p=0.01)$ and CRF $(r=0.89, p=0.000004)$ subjects. $b$, The molar ratio of IGF total IGF to IGF-BP53 varied with IGF-II levels for the control $(r=0.88, p=0.00008)$ and CRF $(r=0.70, p=0.002)$ subjects. $c$, This ratio also varies with the total IGF level for the control $(r=0.86, p=0.0002)$ and CRF $(r=0.85, p=0.00003)$ groups. The controls are represented by the open circles and the CRF subjects are represented by the closed circles.

in adults with CRF is uncertain, although inhibition of IGF action may lead to a negative effect on nitrogen balance (35).

The mechanism for the IGF-BP25 elevation is uncertain, and may be related to an effect of renal failure on either metabolism and clearance or production of this protein. To gain further insight into this question, we further analyzed our data to determine whether physiologic interrelationships of age, IGF, and IGF-BP25 are altered.

In growth hormone deficiency, growth retardation is associated with decreased IGF-I levels and increased serum IGF-binding activity, indicating an inverse relationship between IGF-I and unsaturated IGF-binding activity $(9,21)$, Povoa et al. (14) reported a similar negative correlation between IGF-I levels and IGF-BP25 levels by RIA in acromegalics, but not adults with diabetic nephropathy.

Our data confirm an inverse correlation of IGF-I and IGF$\mathrm{BP} 25$, and we speculate that this may be mediated by growth hormone. An inverse relationship between IGF-II and IGF-BP25 was also observed. Furthermore, an inverse correlation of age with IGF-BP25 was observed for both populations. Inasmuch as the levels of IGF-I and IGF-II are not decreased in CRF, these results suggest that the abnormally high levels of IGF-BP25 may be due to a defect in the the metabolism and clearance of this protein. Alternatively, undefined physiologic mechanisms that account for the inverse relationship of IGF and IGF-BP25 may be disrupted, leading to incomplete feedback and a relative overproduction of IGF-BP25.

Nutritional status may play a role in the elevated IGF-BP25 levels observed for the CRF patients. Overnight and 24-h fasting in normal subjects leads to elevated IGF-BP25 levels, and ac- counts for the usual diurnal variation $(36,37)$.Elevated IGFBP25 levels have also been reported in anorexia nervosa (24). Although IGF-I and IGF-II levels are usually low in malnutrition (38), this relationship does not hold for malnutrition associated with renal failure (39). However, the degree of IGF-BP25 elevation for our study population far exceeds that reported for other more severely malnourished individuals with anorexia nervosa; and the degree of caloric deficiency for our CRF study population showed no correlation with IGF-BP25 levels. The three children with CRF and normal nutritional intake ( $\geq 100 \%$ recommended daily allowance) had significantly greater IGF-BP25 levels as compared to their matched controls. Therefore, the role of malnutrition in elevating IGF-BP25 levels in CRF remains unresolved.

Other investigators have shown that insulin decreases circulating IGF-BP25 levels (40). Insulin levels are usually increased in CRF, probably secondary to a postreceptor defect leading to insulin resistance (41). Our finding of elevated IGF-BP25 levels in CRF suggests, therefore, that the expected inverse relationship of insulin and IGF-BP25 levels may be abnormal. However, we were not able to address this possibility directly, because insulin levels were not determined.

IGF-BP53 is an IGF-binding protein derived from the 150 - to $200-\mathrm{kD}$ IGF/IGF-binding protein complex, and is distinct from IGF-BP25 $(23,42)$. The primary structure of IGF-BP53, based on cDNA cloning, indicates that it has approximately $33 \%$ amino acid sequence homology with IGF-BP25, including 18 conserved cysteine residues (43). Levels of IGF-BP53 peak in midpuberty, and are relatively low in early childhood and adulthood (20). Elevated levels of IGF-BP53 have been reported in adults with 
CRF (20), and our current report extends this observation to children.

Serum IGF-BP53 levels did not positively correlate with IGFBP25 or IGF-binding activity, suggesting different regulatory mechanisms for these two proteins. Unlike IGF-BP25, serum IGF-BP53 is derived from an IGF-saturated fraction of serum (20), and may not function as a dynamic inhibitor of circulating IGF action; although we certainly cannot exclude the possibility that it may inhibit IGF action through another mechanism. Levels of IGF-BP53 should reflect circulating IGF levels, whereas the ratio of IGF to IGF-BP53 should remain constant with relation to age and IGF levels. However, we observed that the ratio of IGF to IGF-BP53 increased with both age and IGF levels for the CRF and control children. This apparent change in the valence of the saturated large mol wt complex is unexplained, but may be related to the accumulation of inactive immunoreactive metabolites of the IGF-BP53 protein in the younger children. The physiologic significance of the elevated IGF-BP53 levels and consequent decreased IGF to IGF-BP53 ratios in CRF is also uncertain, and deserves future investigation.

In summary, we have found elevated levels of immunoassayable IGF-BP25 in children with CRF as compared to healthy age- and sex-matched controls. The data presented suggests that this is due to accumulation of a bioactive form of this IGFinhibitory protein in the presence of disrupted physiologic interrelationships. These data support a role for IGF-BP25 in the growth retardation associated with CRF. We also confirmed that IGF-BP53 is elevated in CRF, although the physiological significance of this latter observation remains uncertain.

Acknowledgments. The authors acknowledge the expert technical assistance of Bonita Baker and Francis Liu, Drs. Malcolm Holliday, Donald Potter, Rose Ellen Morrell, and Bruce Tune for patient referrals, Elizabeth San Luis, R.N., for blood sample collection, and Raksha Shah for the nutritional evaluations.

\section{REFERENCES}

1. Rizzoni G, Broyer M, Guest G, Fine R, Holliday MA 1986 Growth retardation in children with chronic renal disease: scope of the problem. Am J Kidney Dis 7:256-261

2. Warady BA, Kriley M, Lovell H, Farrell SE, Hellerstein E 1988 Growth and development of infants with end-stage renal disease receiving long-term peritoneal dialysis. J Pediatr 112:714-719

3. Powell DR 1988 Renal disease and growth retardation. Growth Genet Horm $4: 1-3$

4. El-Bishti MM, Couahan R, Bloom SR, Chantler C 1978 Hormonal and metabolic responses to intravenous glucose in children on regular hemodialysis. Am J Clin Nutr 31:1865-1869

5. Wassner SJ, Buckingham BA, Kershnar AJ, Malekzadeh MH, Pennisi AJ, Fine RN 1977 Thyroid function in children with chronic renal failure. Nephron 19:236-241

6. Davis FB, Spector DA, Davis PJ, Hirsch BR, Walshe JJ, Yoshida K 1982 Comparison of pituitary-thyroid function in patients with end-stage renal disease and in age- and sex-matched controls. Kidney Int 21:362-364

7. Hintz RL 1981 The somatomedins. Adv Pediatr 28:293-317

8. Powell DR, Rosenfeld RG, Sperry JB, Baker BK, Hintz RL 1987 Serum concentrations of insulin-like growth factor (IGF)-1, IGF-2 and unsaturated somatomedin carrier proteins in children with chronic renal failure. Am J Kidney Dis 10:287-292

9. Hintz RL 1984 Plasma forms of somatomedin and the binding protein phenomenon. Clin Endocrinol Metab 13:31-42

10. Lee PDK, Powell DR, Li CH, Bohn H, Liu F, Hintz RL 1988 High molecular weight forms of insulin-like growth factor II and its binding protein identified by protein immunoblotting. Biochem Biophys Res Commun 152:11311137

11. Zapf J, Schoenle E, Jagars G, Sand I, Grunwald J, Froesch ER 1979 Inhibition of action of non-suppressible insulin-like activity on isolated fat cells by binding to its carrier protein. J Clin Invest 63:1077-1084

12. Powell DR, Rosenfeld RG, Baker BK, Hintz RL 1986 Serum somatomedin levels in adults with chronic renal failure: the importance of measuring insulin-like growth factor (IGF)-I and IGF-II acid chromatographed uremic serum. J Clin Endocrinol Metab 63:1186-1192

13. Goldberg A, Trivedi B, Delmez J, Harter HR, Daughaday WH 1982 Uremia reduces insulin-like growth factor $\mathrm{I}$, increases insulin-like growth factor II and modifies their serum binding protein. J Clin Endocrinol Metab 55:1040-
1045

14. Povoa G, Roovete A, Hall K 1984 Cross-reaction of serum somatomedinbinding protein in a radioimmunoassay developed for somatomedin-binding protein isolated from human amniotic fluid. Acta Endocrinol 107:563-570

15. Crop SLS, Kortleve DJ, Guyda HJ, Posner PI 1984 Immunoassay of a somatomedin-binding protein from human amniotic fluid: levels in fetal, neonatal, and adult sera. J Clin Endocrinol Metab 59:908-915

16. Lee YL, Hintz RL, James PM, Lee PDK, Shively JE, Powell DR 1988 Insulinlike growth factor (IGF) binding protein complementary deoxyribonucleic acid from human HEP G2 hepatoma cells: predicted protein sequence suggests an IGF binding domain different from those of the IGF-I and IGFII receptors. Mol Endocrinol 2:404-411

17. Brinkman A, Groffen C, Kortleve DJ, Geurts van Kessel A, Drop SLS 1988 Isolation and characterization of a cDNA encoding the low molecular weight insulin-like growth factor binding protein (IBP-1). EMBO J 7:2417-2423

18. Powell DR, Lee PDK, Shively JE, Eckenhausin M, Hintz RL 1987 Method for purification of an insulin-like growth factor-binding protein produced by human HEP-G2 hepatoma cells. J Chromatog 420:163-170

19. Rodbard D 1984 Lessons from the computerization of radioimmunoassays: an introduction to the basic principles of modeling. In: Rodbard D, Forti $G$ (eds) Computers in Endocrinology. Raven Press, New York, pp 75-99

20. Baxter RC, Martin JL 1986 Radioimmunoassay of growth hormone- dependent insulinlike growth factor binding protein in human plasma. J Clin Invest 78:1504-1512

21. Hintz RL, Liu F, Kemp SF, Rosenfeld RG 1981 Somatomedin plasma binding proteins in hypopituitarism: changes during growth hormone therapy. J Clin Endocrinol Metab 53:100-104

22. Drop SLS, Kortleve DJ, Guyda HJ 1984 Isolation of a somatomedin-binding protein from pre-term amniotic fluid. Development of radioimmunoassay. $\mathrm{J}$ Clin Endocrinol Metab 59:899-907

23. Baxter RC, Martin JL, Wood MH 1987 Two immunoreactive binding proteins for insulin-like growth factors in human amniotic fluid: relationship to fetal maturity. J Clin Endocrinol Metab 65:423-431

24. Hall K, Lundin G, Povoa G 1988 Serum levels of the low molecular weight form of insulin-like growth factor binding protein in healthy subjects and patients with growth hormone deficiency, acromegaly and anorexia nervosa. Acta Endocrinol 118:321-326

25. Baxter RC, Cowell CT 1987 Diurnal rhythm of growth hormone-independent binding protein for insulin-like growth factors in human plasma. J Clin Endocrinol Metab 65:432-440

26. Rosenfeld RG, Wilson DM, Lee PDK, Hintz RL 1986 Insulin-like growth factors I and II in evaluation of growth retardation. J Pediatr 109:428-433

27. Elgin RG, Busby WH, Clemmons DR 1987 An insulin-like growth factor (IGF) binding protein enhances the biologic response to IGF-I. Proc Nati Acad Sci USA 84:3254-3258

28. Rutanen EM, Pekonen F, Makinen T 1988 Soluble $34 \mathrm{~K}$ binding protein inhibits the binding of insulin-like growth factor I to its cell receptors in human secretory phase endometrium: evidence for autocrine/paracrine regulation of growth factor action. J Clin Endocrinol Metab 66:173-180

29. Ritvos O, Ranta T, Jalkanen J, Suikkari AM, Voutilainen R, Bohn H, Rutanen EM 1968 Insulin-like growth factor (IGF) binding protein from human decidua inhibits the binding and biological action of IGF-I in cultured choriocarcinoma cells. Endocrinology 122:2150-2157

30. Zapf J, Hauri C, Waldvogel M, Froesch ER 1986 Acute metabolic effects and half-lives of intravenously administered insulinlike growth factors I and II in normal and hypophysectomized rats. J Clin Invest 77:1768-1775

31. Guler HP, Zapf J, Froesch ER 1987 Short-term metabolic effects of recombinant human insulin-like growth factor I in healthy adults. $\mathrm{N}$ Engl J Med 317:137-140

32. Bayne ML, Applebaum J, Chicchi GG, Hayes NS, Green BG, Cascieri MA 1988 Structural analogs of human insulin-like growth factor I with reduced affinity for serum binding proteins and the type 2 insulin-like growth factor receptor. J Biol Chem 263:6233-6239

33. Cascieri MA, Saperstein R, Hayes NS, Green BG, Chicchi GG, Applebaum J, Bayne ML 1988 Serum half-life and biological activity of mutants of human insulin-like growth factor I which do not bind to serum binding proteins. Endocrinology 123:373-381

34. Powell D, Lee P, Baxter R, Correa J, Burch W 1989 Insulin-like growth factor binding proteins (IGF BPs) are increased in serum of children with chronic renal failure (CRF) and inhibit cartilage growth in vitro. Kidney Int 35:436

35. Clemmons DR, Underwood LE Dickerson RN, Brown RO, Hak LJ, MacPhee RD, Heizer WD 1985 Use of plasma somatomedin-C/insulin-like growth factor I measurements to monitor the response to nutritional repletion in malnourished patients. Am J Clin Nutr 41:191-198

36. Cotterill AM, Cowell CT, Baxter RT, McNeil D, Silinik M 1988 Regulation of the growth hormone-independent growth factor-binding protein in children. J Clin Endocrinol Metab 67:882-887

37. Yeoh SI, Baxter RC 1988 Metabolic regulation of the growth hormone independent insulin-like growth factor binding protein in human plasma. Acta Endocrinol 119:465-473

38. Soliman AT, Hassan AEHI, Aref MK, Hintz RL, Rosenfeld RG, Rogol AD 1986 Serum insulin-like growth factors I and II concentrations and growth hormone and insulin responses to arginine infusion in children with proteinenergy malnutrition before and after nutritional rehabilitation. Pediatr Res 20:1122-1130

39. Powell DR, Rosenfeld RG, Hintz RL 1988 Effects of growth hormone therapy and malnutrition on the growth of rats with renal failure. Pediatr Nephrol 
$2: 425-430$

40. Suikkari AM, Koivisto VA, Rutanen EM, Yki-Jarvinen H, Karonen SL, Seppala M 1988 Insulin regulates the serum levels of low molecular weight insulin-like growth factor-binding protein. J Clin Endocrinol Metab 66:266272

41. Pederson O, Schmitz O, Hjollund E, Richelsen B, Hansen HK 1985 Postbinding defects of insulin action in human adipoctyes from uremic patients. Kidney Int 27:780-784
42. Baxter RC, Martin JL, Tyler ML, Howden MEH 1986 Growth hormonedependent insulin-like growth factor (IGF) binding protein from human plasma differs from other human IGF binding proteins. Biochem Biophys Res Commun 138:1256-1261

43. Wood WI, Cachianes G, Henzel WJ, Winslow GA, Spencer SA, Hellmiss R, Martin JL, Baxter RC 1988 Cloning and expression of the growth hormonedependent insulin-like growth factor-binding protein. Mol Endocrinol 2:1176-1185 